\title{
Pemerolehan Bahasa Anak Berkebutuhan Khusus (Tunarungu) dalam Memahami Bahasa
}

\author{
${ }^{1}$ Nur Haliza ${ }^{*},{ }^{2}$ Eko Kuntarto, ${ }^{3}$ Ade Kusmana \\ Pascasarjana Universitas Jambi \\ ${ }^{1}$ E-mail: nurhaliza301097@ gmail.com \\ 2E-mail: abieko28@ gmail.com \\ ${ }^{3}$ Email: dr.akusmana@gmail.com
}

\author{
Pengiriman: 29/04/2020; Diterima: 15/11/2020; Publikasi: 23/11/2020 \\ DOI: $10.31629 /$ jermal.v1i2.2214
}

\begin{abstract}
Abstrak
Anak tunarungu adalah anak yang mengalami gangguan pendengaran yang diklasifikasikan kedalam tuli (deaf) dan kurang pendengaran (hard of hearing). Dampak langsung dari ketunarunguan adalah terhambatnya komunikasi verbal/lisan, baik secara berbicara (ekspresif) maupun memahami pembicaraan orang lain (reseptif). Pemerolehan bahasa pertama anak tunarungu dapat dilakukan dengan komunikasi total. Komunikasi total merupakan sistem komunikasi paling efektif karena selain menggunakan bentuk komunikasi secara lisan atau disebut oral, dengan kegiatan membaca, menulis, membaca ujaran, juga dilengkapi dengan bentuk isyarat. Tujuan penelitian ini adalah untuk mengetahui pemerolehan bahasa anak berkebutuhan khusus (tunarungu) dalam memahami bahasa. Subjek dalam penelitian ini adalah anak berkebutuhan khusus yang mengalami ketunarunguan wicara (tunarungu) sedangkan objek penelitian ini difokuskan hanya pada satu anak yaitu Mila Erdita anak usia 15 tahun. Penelitian ini merujuk pada studi kasus dengan jenis penelitian deksriptif. Teknik pengumpulan data dalam penelitian ini akan dilakukan melalui tiga cara yaitu; teknik observasi, teknik wawancara, dan teknik dokumentasi. Hasil penelitian ini menunjukkan anak tunarungu dapat memperoleh bahasa seacara komunikasi total menggunakan bentuk komunikasi secara lisan atau disebut oral, dengan kegiatan membaca, menulis, membaca ujaran, juga dilengkapi dengan bentuk isyarat dengan menggunakan kalimat-kalimat sederhana.
\end{abstract}

Kata Kunci: bahasa anak, pemerolehan bahasa, tunarungu (tunawicara).

\begin{abstract}
Children with hearing impairment are children with hearing loss who are classified into deaf and hard of hearing. The direct impact of disability is the obstruction of verbal / verbal communication, both speaking (expressive) and understanding the conversations of others (receptive). Obtaining the first language of a deaf child can be done with total communication. Total communication is the most effective communication system because in addition to using a form of communication orally or called oral, the activity of reading, writing, reading utterances, is also equipped with a form of cues. The purpose of this study was to determine the acquisition of language of children with special needs (deaf) in understanding language. Subjects in this study are children with special needs who experience speech impairment (hearing impairment) while the object of this study is focused on only one child, Mila Erdita, a 15-year-old child. This research refers to case studies with descriptive research type. Data collection techniques in this study will be done in three ways, namely; observation techniques, interview techniques, and documentation techniques. In this research, data processing that will be done is to describe the speech data of deaf children to see the acquisition of children's vocabulary. The results of this study indicate that deaf children can obtain a language of total communication using a form of communication orally or called oral, with the activities of reading, writing, reading utterances, also equipped with signs.
\end{abstract}

Keywords: Child language, acquisition of language, hearing impairment. 


\section{PENDAHULUAN}

Proses penguasaan bahasa anak tidak lepas dari peran orang tua yang berperan merespon segala percakapan yang diungkapkan anaknya. Orang dengan kecacatan rungu wicara mengalami kesulitan dalam mengembangkan kemampuan berpikir karena mereka mengalami hambatan dalam penguasaan bahasa sehingga kemampuan mewujudkan ke dalam lambang-lambang bahasa pun terganggu. Seseorang dapat berbahasa harus ditunjang oleh fungsi pendengaran yang baik, sebab pemerolehan bahasa terbentuk melalui proses meniru dan mendengar.

Menurut (Christine, 2016) mengemukakan bahwa bahasa diperoleh melalui kegiatan menirukan unsur-unsur bahasa mulai terbentuk, anak akan mencoba mengungkap sendiri melalui kata-kata sebagai awal dari kemampuan bahasa ekspresif. Dengan kata lain, potensi aktulisasi diri dan kemampuan mewujudkan fungsi sosialnya terhambat karena masalah kemampuan berbahasa dan bukan karena cacat rungunya. Akibat gangguan komunikasi dan bahasa menimbulkan masalah yang lebih kompleks antara lain pada aspek preseptual, kognitif, emosi dan sosial, kesulitan mempelajari keterampilan vokasional.

Gangguan berbahasa juga menimbulkan masalah penerimaan orang tua dan masyarakat yang berdampak pada kekeliruan cara pandang dan perlakuan. Dampak langsung dari ketunarunguan adalah terhambatnya komunikasi verbal/lisan, baik secara berbicara (ekspresif) maupun memahami pembicaraan orang lain (reseptif), sehingga sulit berkomunikasi dengan lingkungan orang mendengar yang lazim menggunakan bahasa verbal sebagai alat komunikasi. Hambatan dalam berkomunikasi tersebut berakibat juga pada hambatan dalam proses pendidikan dan pembelajaran anak tunarungu. Namun demikian anak tunarungu memiliki potensi untuk belajar berbicara dan berbahasa.

Anak tunarungu tidak dapat belajar bahasa atau memperoleh kemampuan berbahasa atau berbicara dengan cara yang normal. Pemerolehan bahasa pertama anak tunarungu dapat dilakukan dengan komunikasi total. Komunikasi total merupakan sistem komunikasi paling efektif karena selain menggunakan bentuk komunikasi secara lisan atau disebut oral, dengan kegiatan membaca, menulis, membaca ujaran, juga dilengkapi dengan bentuk isyarat.

Isyarat layaknya bahasa alami untuk tunarungu, walaupun bentuknya berbeda di beberapa daerah namun ada sistem isyarat bahasa Indonesia yang dibakukan. Melihat permasalahan yang ada maka, tujuan penelitian ini adalah untuk mengetahui pemerolehan bahasa anak berkebutuhan khusus (tunarungu) dalam memahami bahasa.

\section{METODE PENELITIAN}

Subjek dalam penelitian ini adalah anak berkebutuhan khusus yang mengalami ketunarunguan wicara (tunarungu) sedangkan objek penelitian ini difokuskan hanya pada satu anak yaitu Mila Erdita anak usia 15 tahun yang lahir pada tanggal 13 April 2005 di Kota Jambi, anak dari pasangan Susendi dan Ayu Sushinta sehari-hari menggunakan bahasa indonesia.

Penelitian ini menggunakan penelitian kualitatif. Penelitian kualitatif adalah penelitian yang menghasilkan prosedur analisis yang tidak menggunakan prosedur analisis statistik atau cara kuantifikasi lainnya (Meleong 2004). Penelitian ini merujuk pada studi kasus dengan jenis penelitian deksriptif kualitatif. Penelitian dilakukan sematamata hanya berdasarka pada fakta yang ada atau fenomena yang terjadi yaitu pemerolehan kosa kata dan pemerolehan bahasa Mila Erdita anak usia 15 Tahun dalam tuturan sintaksis. Adapun tuturan yang hendak diteliti merupakan tuturan 
bermakna berupa kalimat-kalimat yang dengan sadar di ucapkan dalam keadaan yang tidak formal oleh subjek penelitian. Tuturan tersebut dianalisis untuk memperoleh sejauh mana hasil penguasaan bahasa. Lokasi penelitian di SLB Negeri 1 Kota Jambi Jln. Sersan Muslim Rt. 24 Telp (0741) 40525 Thehok Jambi Selatan Kp (36138).

Teknik pengumpulan data dalam penelitian ini akan dilakukan melalui cara yaitu; teknik observasi dan teknik dokumentasi. Dalam penelitian ini pengolahan data yang akan dilakukan adalah mendeskripsikan data ujaran anak tunarungu untuk melihat pemerolehan kosa kata anak. Paparan hasil pengolahan data akan disajikan dalam bentuk deskripsi tentang pemerolehan kosakata anak tunarungu.

Deskripsi ini menggambarkan tata bahasa pemerolehan kalimat yang sederhana yang dikuasai dan diketahui atau diperoleh anak tunarungu pada usia 12-18 tahun. Tahap analisis data sebagaii berikut. Peneliti menyajikan analisis data dengan menggunakan analisis deskriptif, yang menjelaskan dan memaparkan bentuk-bentuk kalimat sederhana yang diujarkan oleh anak usia 12-18 tahun.

\section{HASIL PENELITIAN DAN PEMBAHASAN}

\section{Pemerolehan Bahasa Anak Tunarungu}

Menurut Winarsih (2010), pemerolehan bahasa diartikan sebagai proses perkembangan alami bahasa pertama yang terjadi tanpa disadari dan digunakan untuk keperluan komunikasi semata tanpa kesadaran adanya kaidah bahasa. Chaer (2003) mengatakan bahwa pemerolehan bahasa adalah proses yang berlangsung di dalam otak seseorang ketika memperoleh bahasa pertamanya atau bahasa ibunya. Jadi, pemerolehan bahasa berkenaan dengan bahasa pertama. Eko Kuntarto, Suhartono, n.d. mengatakan bahwa pemerolehan bahasa biasanya tidak menyadari adanya fakta bahwa mereka memperoleh bahasa.

Menurut Widia \& The, n.d. masa pemerolehan bahasa anak tunarungu tidak dapat dilalui seperti halnya anak yang bisa mendengar. Jika anak sehat mampu menghubungkan pengalaman dan lambang bahasa melalui pendengaran, pada anak tunarungu tidak. Hal ini disebabkan adanya disfungsi pada pendengarannya. Anak tunarungu memperoleh bahasanya lebih difokuskan melalui fungsi penglihatannya. Namun, tidak menutup kemungkinan dengan memaksimalkan fungsi pendengarannya, bagi siswa tunarungu yang kurang dengar.

Yosinta Desy K (2009) mengatakan bahwa pemerolehan bahasa anak tunarungu yaitu memahami ujaran melalui media membaca ujaran. Membaca ujaran merupakan unsur atau dasar sistem bahasa batinnya. Batini anak tunarungu terdiri dari kata-kata sebagaimana tampil pada gerak dan corak sebagai pengganti bunyi bahasa yang berupa vokal, konsonan, dan intonasi pada anak mendengar.

Menurut Gunawan (2016) membaca ujaran merupakan kegiatan yang bukan hanya mencakup sekedar pengamatan gerak bibir tetapi meliputi pengamatan, atas bahasa tubuh, ekspresi, dan konteks secara keseluruhan dimana komunikasi ini berlangsung. Untuk mencapai keterampilan dalam membaca bahasa ujaran, seseorang dituntut untuk memiliki suatu taraf penguasaan bahasa tertentu, karena di dalam membaca ujaran terdapat kompensasi dari pengetahuan bahasa yang telah dimiliki dengan pengetahuan tentang pokok pembicaraan. Oleh karena itu, membaca ujaran merupakan sarana yang berharga dalam program latihan komunikasi bagi anak tunarungu apabila memenuhi persyaratan seperti keterampilan berbahasa tertentu, pengetahuan tentang topik yang dibicarakan dan persyaratanteknis lain seperti berhadapan wajah pada jarak yang tak terlalu jauh dari lawan bicara, 
penerangan yang cukup dan lain sebagainya.

Keterbelakangan pemerolehan bahasa pada bayi tunarungu dari keluarga yang mendengar ini salah satunya disebabkan oleh terhentinya interaksi antara ibu dan bayi karena ibu tidak dapat menangkap pesan komunikasi bayi atau sebaliknya; ungkapan-ungkapan ibu tidak mendapat respon yang baik dari bayinya sehingga komunikasi tidak berjalan dengan baik. Pemerolehan bahasa pertama atau bahasa ibu penyandang tunarungu dapat dikategorikan menjadi: 1) bagi yang memiliki orang tua tunarungu akan berkomunikasi dengan menggunakan media isyarat; 2) bagi yang memiliki orang tua mendengar dan atau tunarungu berkomunikasi dengan menggunakan media isyarat dan oral; dan 3) bagi yang memiliki orang tua dapat mendengar dan berkomunikasi dengan menggunakan media oral.

Komunikasi verbal adalah komunikasi dengan menggunakan oral (lisan, bicara) tulisan dan membaca ujaran. Oral adalah suatu cara dalam berkomunikasi dengan menggunakan bahasa lisan sebagai alat untuk berkomunikasi. Menurut Gunawan (2016) komunikasi oral yaitu; (1) Suatu sistem komunikasi yang menggunakan bicara, sisa pendengaran, baca ujaran, dan atau rangsangan vibrasi serta perabaan (vibrotaktil) untuk suatu percakapan spontan; (2) Suatu sistem pendidikan yang mana kegiatan belajar mengajar berlangsung dengan menggunakan bahasa lisan dan tulisan.

Keunggulan oral dibandingkan bahasa isyarat, yaitu (1) Kecepatan berbicara jauh lebih cepat daripada berbahasa isyarat. (2) Bahasa bicara lebih fleksibel, baik pembicara maupun lawan bicara lebih bebas. (3) Isyarat bersifat terlalu afektif, cenderung menyebabkan kurang terkendalinya perasaan. (4) Dengan isyarat ada kecenderungan untuk memeragakan pikiran atau hal yang kongkret, emosional, atau situasional saja.
(5) Bila seseorang berbicara, maka "pesan" atau ungkapan seolah-olah keluar dari diri orang itu agar sampai pada lawan bicara. Sementara itu dengan berisyarat seseorang akan lebih terpusat pada diri sendiri, kurang memberi kesan adanya sesuatu yang "keluar" ke orang lain, bahkan perhatian lawan bicara lebih terarah terhadap gerak tangan penyampai pesan.

Berdasarkan hasil observasi anak mampu merangkai sebuah kalimat sederhana seperti perkenalan yaitu "siapa kamu nama?", "aku nama ani”, "kelas kamu berapa", "sekolah kamu mana", tau kamu apa".

Dapat disimpulkan bahwa pemerolehan bahasa anak tunarungu memerlukan layanan khusus untuk mengembangkan kemampuan berbahasa dan berbicara, sehingga dapat meminimalisi dampak dari ketunarunguan yang dialaminya.

\section{Perkembangan Bahasa Anak Rungu Wicara (Tunarungu)}

Anak tunarungu merupakan salah satu dari anak berkebutuhan khusus yang rata-rata memiliki kemampuan intelektual normal bahkan di atas normal dan pertumbuhan fisik yang sehat. Kemampuan bicara mereka menjadi berada di bawah anakanak pada umumnya karena disebabkan minimnya perolehan informasi melalui indra pendengarannya. Sebagaimana istilah tunarungu diambil dari tuna dan rungu, bahwa tuna berarti kurang dan rungu berarti pendengaran. Dari masingmasing derajat ketunarunguan pada penyandang tunarungu memiliki konsekuensi tersendiri dalam masalah komunikasi bahasa.

Menurut Hernawati (2007) anak tunarungu merupakan anak yang mengalami gangguan pendengaran yang diklasifikasikan kedalam tuli (deaf) dan kurang pendengaran (hard of hearing). Siswomartono (2007) mengatakan bahwa ketunarunguan memberikan dampak terhadap perkembangan bahasa dan 
bicaranya terutama bagi anak tunarungu sejak lahir (prabahasa).

Perkembangan berbahasa dan berbicara mereka menjadi terhambat, sehingga berakibat juga pada keterhambatan dalam pengembangan potensinya. Kondisi ketidakmampuan seseorang untuk mendengar sesuatu, baik secara total maupun sebagian, dapat kita sebut sebagai tunarungu. (Gunawan, 2016) mengatakan bahwa orang yang tulli adalah seorang yang mengalami ketidak mampuan mendengar biasanya pada tingkat 70 desiBeli $(\mathrm{dB})$ atau lebih sehingga akan mengalami ksulitan untuk dapat mengerti atau memahami pembicaraan orang lain.

\begin{tabular}{|c|c|c|}
\hline \multicolumn{3}{|r|}{ Tabel 1} \\
\hline No & $\mathbf{d B}$ & Keterangan \\
\hline 1 & $0 \mathrm{~dB}$ & $\begin{array}{c}\text { Menunjukkan pedengaran yang } \\
\text { optimal }\end{array}$ \\
\hline 2 & $0-26 \mathrm{~dB}$ & $\begin{array}{c}\text { Masih mempunyai pendengaran } \\
\text { yang normal }\end{array}$ \\
\hline 3 & $27-40 \mathrm{~dB}$ & $\begin{array}{c}\text { Kesulitan mendengar bunyi yang } \\
\text { jauh }\end{array}$ \\
\hline 4 & $41-55 \mathrm{~dB}$ & $\begin{array}{l}\text { Membutuhkan alat bantu dengar } \\
\text { dan terapi bicara }\end{array}$ \\
\hline 5 & $56-70 \mathrm{~dB}$ & Tergolong tunarungu agak berat \\
\hline 6 & $71-90 \mathrm{~dB}$ & Tunarungu berat \\
\hline 7 & $\begin{array}{l}\text { Di atas } 91 \\
\mathrm{~dB}\end{array}$ & $\begin{array}{l}\text { Keatas tergolong tunarungu berat } \\
\text { sekali }\end{array}$ \\
\hline
\end{tabular}

Anak yang pendengarannya kurang baik, tetapi "'loss of hearing"-nya belum sampai $95 \mathrm{~dB}$ disebut kurang dengar (hard of hearing). Jika kehilangan pendengaran lebih dari $95 \mathrm{~dB}$, kita memakai istilah tuli. Barangkali anak tuli itu masih mempunyai sisa-sisa pendengaran, tetapi tidak cukup untuk mendengar dan menangkap percakapan, biarpun dengan alat-alat pendengaran yang terbaik. Ketunarunguan menyebabkan anak dari lahir bisu, dan jika tidak ada campur tangan pedagogis didaktis yang tepat, maka dalam perkembangannya anak itu akan tetap bisu seumur hidupnya, dan tidak mempunyai alat komunikasi yang baik untuk berintegrasi dalam mesyarakat.

Penyandang tunarungu memiliki kendala tersendiri dalam hal komunikasi verbal/lisan, baik dalam berbicara maupun dalam memahami pembicaraan orang lain. Ketunarunguan akan mengakibatkan terhambatnya perkembangan anak, baik itu tingkat intelegensi, bicara, emosi, sosial, maupun kepribadiannya, diperlukan adanya pendidikan komunikasi verbal dan media belajar dan pelatihan penunjang semenjak usia dini. Dalam mengembangkan kemampuan berbahasa dan berbicara anak tunarungu memerlukan layanan khusus untuk meminimalis dampak yang disebabkan oleh ketunarunguan yang dialaminya. Dalam mengembangkan kemampuan berbahasa pada anak tunarungu, kita perlu memahami pemerolehan bahasa yang terjadi pada anak mendengar dan juga yang terjadi pada anak tunarungu. (Hernawati, 2007) mengatakan bahwa pemerolehan bahasa anak yang mendengar berawal dari adanya pengalaman atau situasi bersama antara bayi dan ibunya atau orang lain yang berarti dalam lingkungan terdekatnya. Melalui pengalaman tersebut, anak 'belajar' menghubungkan pengalaman dan lambang bahasa yang diperoleh melalui pendengarannya. Proses ini merupakan dasar berkembangnya bahasa batini (inner language).

Setelah itu, anak mulai memahami hubungan antara lambang bahasa dengan benda atau kejadian yang dialaminya sehingga terbentuklah bahasa reseptif anak. Dengan kata lain anak memahami bicara lingkungannya (bahasa reseptif auditori). Setelah bahasa reseptif auditori terbentuk, anak mulai mengungkapkan diri melalui kata-kata sebagai awal kemampuan bahasa ekspretif auditori atau berbicara, meskipun pada dasarnya perkembangan ke arah bicara muncul lebih dini lagi, yaitu dengan adanya masa meraban.

Kemampuan itu semua berkembang melalui pendengarannya (auditori). Setelah anak memasuki usia sekolah, penglihatannya berperan dalam perkembangan bahasa melalui kemampuan membaca (bahasa reseptif visual) dan 
menulis (bahasa ekspresif visual). Dengan demikian tersedia tiga alternatif, yaitu: isyarat, membaca dan membaca ujaran. Media membaca ujaran merupakan pilihan yang tepat disbanding isyarat dan membaca. Dengan kemajuan teknologi pendengaran saat ini, maka sisa pendengarannya dapat dioptimalkan untuk menstimulasi anak tunarungu dalam perolehan bahasa. Apabila membaca ujaran menjadi dasar pengembangan bahasa batini anak tunarungu, kita dapat melatih anak tunarungu untuk menghubungkan pengalaman yang diperolehnya dengan gerak bibir dan mimik pembicara. Bagi anak kurang dengar yang menggunakan alat bantu dengar, dapat menghubungkannya dengan lambang bunyi bahasa (lambang auditori). Setelah itu, anak tunarungu mulai memahami hubungan antara lambang bahasa (visual \& auditori) dengan benda atau kejadian sehari-hari, sehingga terbentuklah bahasa reseptif visual/auditori. Sama halnya seperti anak mendengar, kemampuan bahasa ekspresif (bicara) baru dapat dikembangkan setelah memiliki kemampuan bahasa reseptif. Selanjutnya anak tunarungu dapat mengembangkan kemampuan bahasa reseptif visual (membaca) dan bahasa ekspresif visual (menulis). Demikian perilaku bahasa verbal yang dapat terjadi pada anak tunarungu.

\section{Komunikasi Total}

Menurut (Noviantari, 2010) komunikasi total adalah salah satu pandangan atau konsep komunikasi bagi orang dengan kecacatan rungu wicara, yang bertujuan mencapai komunikasi yang efektif antara sesama orang dengan kecacatan rungu wicara ataupun orang dengan kecacatan rungu wicara dengan masyarakat luas dengan menggunakan media berbicara, membaca bibir, mendengar, dan berisyarat secara terpadu. Komunikasi total bukanlah suatu metode pengajaran cara komunikasi, melainkan dapat diumpamakan sebagai tujuan pendidikan untuk mencapai kemampuan berkomunikasi yang baik.

\section{Menurut (Bunawan,}

2009)

komunikasi total ialah konsep pendidikan anak tunarungu yang mendukung penggunaan semua media komunikasi untuk mengembangkan kemampuan berbahasa. Persyaratan utama yang harus dipenuhi dalam berkomunikasi total adalah digunakannya dalam kebiasaan sehari-hari melalui percakapan sesuai dengan situasi. Persyaratan adalah kita sebagai pengguna, petugas, intstruktur terlebih dahulu harus memiliki minat dan kemampuan berkomunikasi total.

Menurut (Gunaman, komunikasi total adalah pendekatan dalam pendidikan bagi kaum tunarungu yang menganjurkan penggunaan berbagai bentuk media komunikasi untuk meningkatkan keterampilan berbahasa. Komunikasi total adalah falsafah yang mencakup cara komunikasi aural, manual dan oral sehingga terjadi komunikasi yang efektif dengan dan diantara kaum tunarungu.

Berkomunikasi dengan model komunikasi total berarti mengorganisasikan bicara, isyarat, ejaan, jari dan gesti untuk bahu membahu membentuk keutuhan pikiran dan perasaan yang dimunculkan dalam keutuhan ketatabahasaan. Tata bahasa disini adalah tata bahasa Indonesia. Dalam proses komunikasi untuk menangkap ekspresi tersebut melalui mendengar, membaca ujaran, dan membaca isyarat. Jadi, komponen komunikasi total adalah bicara, isyarat, ejaan jari, mendengar, membaca ujaran, dan membaca isyarat.

\section{1) Bicara}

Bicara adalah ekspresi bahasa secara lisan yang diproses dengan menggunakan alat bicara (infirasi, phonasi, artikulasi, dan resonansi) yang menghasilkan bunyi-bunyi bahasa. Bunyi-bunyi bahasa terdiri dari bunyo bahsa terkecil pembeda makna (vokal, diftong, cluster) dan satuan gramatik yang bermakna (kata, frase, klausa dan kalimat).

\section{2) Sistem Isyarat \\ a. Isyarat dan Sistem Isyarat}


Isyarat adalah setiap gerakan tertentu dari tubuh dan anggota tubuh yang memiliki makna tertentu sehingga menjadi sebuah simbol. Contoh geleng-geleng kepala yang bermakna tidak tahu, melambaikan tangan yang bermaka memanggil. Isyarat-isyarat semacam ini biasa digunakan pelaku komunikasi dalam proses komunikasi.

Orang dengan kecacatan rungu wicara juga menggunakan isyarat-isyarat yang digunakan di antara mereka dan hanya mereka yang mengerti. Isyaratisyarat tersebut tidak memiliki sistem tertentu. Isyarat-isyarat dalam komunikasi total disusun atau ditata dalam sebuah sistem. Karenanya disebut sistem isyarat yang kaidah-kaidahnya berdasarkan pada sistem atau aturan bahasa baku Bahasa Indonesia. Misalnya, setiap bunyi bahasa atau fonem berfungsi sebagai pembeda makna, maka ketentuan ini juga digunakan dan berlaku dalam sistem isyarat. Setiap isyarat melambangkan satu kata. Setiap isyarat mempunyai makna konseptual dan kontekstual sebagaimana kata dalam bahas lisan.

\section{b. Komponen Pembeda Makna dalam Isyarat}

1. Penampil; yaitu tangan atau bagian tangan yang digunakan untuk membentuk isyarat

2. Posisi; yaitu kedudukan tangan atau kedua tangan terhadap pengisyarat

3. Tempat; yaitu bagian badan yang menjadi tumpuan awal isyarat dibentuk atau arah akhir isyarat.

4. Arah; yaitu gerak penampil ketika membentuk isyarat

5. Frekuensi; yaitu jumlah gerak penampil ketika isyarat dibentuk.

Dalam berbicara makna ditentukan oleh bunyi segmental dan supra segmental yang ditunjang dengan mimik, gerak tangan, kerut dahi, gerak tubuh atau bahasa tubuh (gesti) dan sebagainya. Demikian juga dalam sistem isyarat, penunjang yang berfungsi menekankan atau memperjelas makna juga ada. Dalam hal ini berupa mimik muka, gerak tubuh, kecepatan gerak, dan kelenturan gerak.

\section{c. Abjad Jari}

Abjad jari atau ejaan jari adalah gerakan jari-jari tangan kanan dan kiri yang dibentuk sedemikian rupa untuk menggambarkan atau mengeja huruf-huruf dan angka-angka. Abjad jari digunakan untuk mengisyaratkan nama diri, singkatan, akronim, dan kata yang belum ada isyaratnya. Abjad jari yang digunakan dalam sistem isyarat ialah abjad jari internasional dengan penyesuaian.

\section{3) Mendengar}

Dalam komunikasi total, peran pendengaran adalah menerima pesanpesan komunikasi yang disampaikan melalui komponen bicara. Potensi pendengaran yang masih ada perlu dioptimalkan agar berfungsi dalam menerima pesan yang disampaikan secara lisan dengan cara menyimak. Oleh karena itu, bagi orang dengan kecacatan rungu wicara yang masih memiliki sisa kemampuan mendengar dan yang menggunakan Alat Bantu Mendengar (ABM) perlu diberi latihan mendengar atau menyimak dalam Bina Komunikasi Presepsi Bunyi dan Irama (BKPBI)

\section{4) Membaca Ujaran}

Menurut (Nurdina, 2015) kemampuan membaca ujaran pada hakikatnya merupakan kemampuan yang harus dimiliki oleh setiap anak tunarungu dalam menjalin komunikasi atau melakukan interaksi sosial yang prinsipnya pada pendekatan oral. Membaca ujaran merupakan salah satu komponen komunikasi total. Membaca ujaran juga merupakan aspek reseptif secara visual atau penglihatan. Membaca ujaran diguanak untuk menangkap pesan yang disampaikan komunikasi melalui bicara, isyarat, ejaaan jari, mimik muka dan bahasa tubuh (gesti) lainnya. Mendengar, membaca ujaran, membirat (membaca isyarat) harus difungsikan untuk bekerja sama, bahu membahu menangkap keutuhan pesan yang disampaikan komunikasi melalui bicara, isyarat, ejaan 
jari, mimik muka, dan bahasa tubuh (gesti). Membirat adalah kecakapan reseptif untuk menangkapkan pesan yang disampaikan melalui isyarat dan ejaan jari.

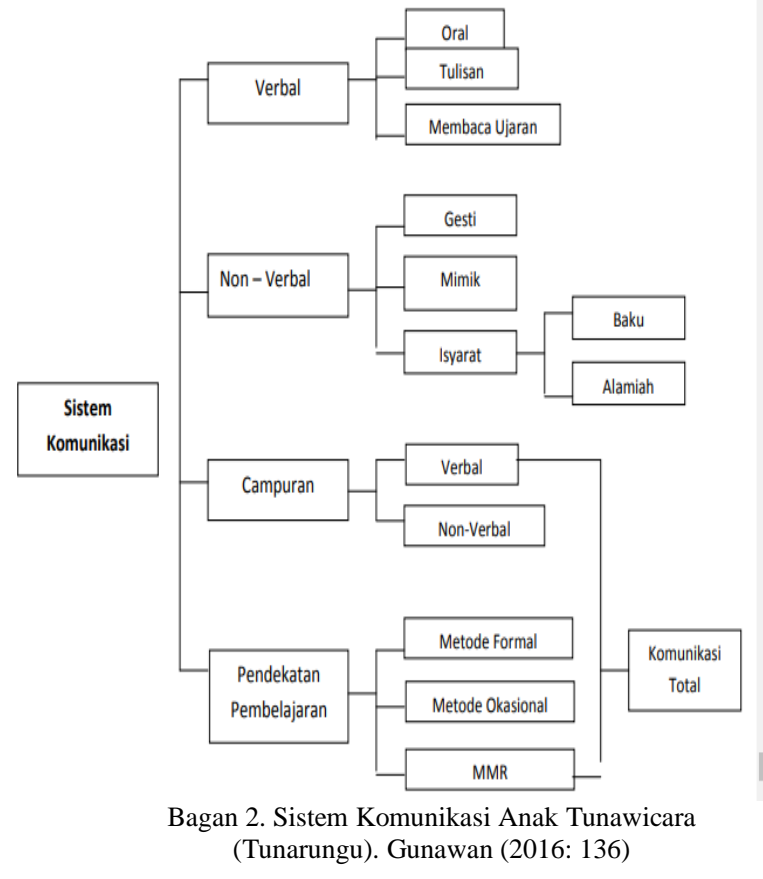

\section{SIMPULAN}

Anak tunarungu merupakan anak yang mengalami gangguan pendengaran yang diklasifikasikan kedalam tuli (deaf) dan kurang pendengaran (hard of hearing). Ketunarunguan memberikan dampak terhadap perkembangan bahasa dan bicaranya terutama bagi anak tunarungu sejak lahir (prabahasa). Perkembangan berbahasa dan berbicara mereka menjadi terhambat, sehingga berakibat juga pada keterhambatan dalam pengembangan potensinya. Kondisi ketidakmampuan seseorang untuk mendengar sesuatu, baik secara total maupun sebagian, dapat kita sebut sebagai tunarungu.

Pemerolehan bahasa anak tunarungu yaitu memahami ujaran melalui media membaca ujaran dan komunikasi total. Membaca ujaran merupakan sarana yang berharga dalam program latihan komunikasi bagi anak tunarungu apabila memenuhi persyaratan seperti keterampilan berbahasa tertentu, pengetahuan tentang topik yang dibicarakan dan persyaratan teknis lain seperti berhadapan wajah pada jarak yang tak terlalu jauh dari lawan bicara, penerangan yang cukup dan lain sebagainya.

Jadi pemerolehan bahasa anak tunarungu melalui komunikasi total yang terdiri dari bicara, isyarat, ejaan jari, mendengar, membaca ujaran, dan membaca isyarat.

\section{REFERENSI}

Bunawan, L. (2009). Komunikasi Total Panduan Untuk Penyelenggaraan Pendidikan Tunarungu. Depertemen Pendidikan dan Kebudayaan Pusat Pengembangan Kurikulum dan Sarana Pendidikan.

Chaer, A. (2003). Psikolinguistik Kajian Teoritik. Jakarta: PT Reneka Cipta.

Christine, J. (2016). Pemerolehan Bahasa Anak Tunarungu. Jpp Paud Untirta, Vol. 3 No.

Gunawan, D. (2016). Modul Guru Pembelajaran SLB Tunarungu . Bandung: PPPPTK TK DAN PLB.

Hernawati, T. (2007). Pengembangan

Kemampuan Berbahasa Dan

Berbicara Anak Tunarungu. JASSI_ JASSI_JASSI_JASSI_anakku, 7, 101-110.

Kuntarto, E, dkk. (2017). Dasar-dasar Psikolinguistik Naskah Hibah Buku Nasional. Direktorat Sumber Daya Manusia Kementrian Riset, Teknologi, dan Pendidikan Tinggi.

Moleong, L. J. (2014). Metodologi Penelitian Kualitatif. Bandung: PT Remaja Rosdakarya.

Noviantari. (2010). Panduan Pelaksanaan Komunikasi Total Bagi Orang Dengan Kecacatan Rungu Wicara. Direktorat Rehabilitasi Sosial Orang Dengan Kecacatan Kementerian Sosial Republik Indonesia.

Nurdina, A. (2015). Studi Kasus Tentang Kemampuan Membaca Ujaran Anak Tunarungu Di Slb- B Dena Upakara Wonosobo. negeri yogyakarta. 
N. Haliza, E. Kuntarto, \& A. Kusmana. Pemerolehan Bahasa Anak Berkebutuhan Khusus (Tunarungu)

dalam Memahami Bahasa

Siswomartono S. (2007). Cara Mudah Belajar SIBI (Sistem Isyarat Bahasa Indonesia). Federasi Nasional untuk Kesejahteraan Tunarungu Indonesia (FNKTRI): Jakarta.

Widia, Y. A., \& The. (n.d.). Pemerolehan

Kosakata Anak Tunarungu

Berdasarkan Kelas Kata Bahasa

Indonesia Di Sdlb Karya Mulia Ii

Surabaya: Kajian Psikolinguistik.

Skriptorium, 1(2), 129-142.

Winarsih, M. (2010). Pembelajaran

Bahasa Bagi Anak Tunarungu.

Perspektif Ilmu Pendidikan, 22, 103113.
Yosinta desy k. (2009). Pemerolehan Bahasa Indonesia Anak Tunarungu Usia 7-10 Tahun ( Studi Kasus Pada Tina Dan Viki ). muhammadiyah surakarta. 